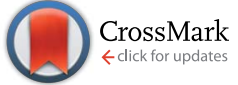

Cite this: RSC Adv., 2016, 6, 43719
Received 25th January 2016 Accepted 25th April 2016

DOI: $10.1039 / c 6 r a 02222 g$

www.rsc.org/advances

\section{Biphenyl derivatives containing trimethylsilyl benzyl ether or oxime groups as probes for $\mathrm{NO}_{2}$ detection $\uparrow$}

\author{
L. Alberto Juárez, abd Ana M. Costero, ${ }^{\text {abd }}$ Margarita Parra, ${ }^{\text {abd }}$ Salvador Gil, ${ }^{\text {abd }}$ \\ Javier Ródenas, ${ }^{\text {ab }}$ Félix Sancenón ${ }^{\text {acd }}$ and Ramón Martínez-Máñez ${ }^{\star a c d}$
}

Four probes based in the use of a biphenyl moiety and functionalized with trimethylsilyl benzyl ether (P1 and P3) and oxime (P2 and P4) groups have been prepared and tested as optical probes for the detection of $\mathrm{NO}_{2}$. Reaction of $\mathrm{NO}_{2}$ with acetonitrile solutions of P2-P4 resulted in the formation of aldehydes 7 and 8 with a concomitant redshift of the absorption bands. Probe P2 displayed a bathochromic shift of $45 \mathrm{~nm}$ upon reaction with $\mathrm{NO}_{2}$ and was able to detect this poisonous gas at concentrations as low as 0.02 ppm. P2 was highly selective against $\mathrm{NO}_{2}$ and other gases (i.e. $\mathrm{NO}, \mathrm{CO}_{2}, \mathrm{H}_{2} \mathrm{~S}, \mathrm{SO}_{2}$ ) and vapours of organic solvents (i.e. acetone, hexane, chloroform, acetonitrile or toluene) had no effect in the optical properties of the probe.

\section{Introduction}

Nitrogen oxides (NOx) are formed in large quantities from fuel combustion in cars, trucks and power plants; ${ }^{1}$ they are a major problem in urban areas and are linked to many respiratory diseases. $^{2}$ From a chemical point of view NOx mainly refers to the sum of nitric oxide (NO) and nitrogen dioxide $\left(\mathrm{NO}_{2}\right)$, although other nitrogen species can also be included, such as nitrous and nitric acids. Together with the adverse effects of direct exposure to NOx on human health, it is also remarkable its contribution to ground level ozone and fine particle pollution. Hence, strict regulations regarding levels of nitrogen oxides are currently applied by governments and the monitorization of NOx levels based in reliable analytical methods is of great interest. $^{3}$

Among NOx species, $\mathrm{NO}_{2}$ causes a range of harmful effects on lungs such as increased inflammation of the airways, worsened cough and wheezing, reduced lung function, increased asthma attacks and increased susceptibility to respiratory infection. ${ }^{4}$ All these problems are more important for children and older adults. ${ }^{5}$ Due to the ubiquitous presence of $\mathrm{NO}_{2}$, the development of selective and sensitive sensing methods for its detection is a hot

\footnotetext{
${ }^{a}$ Instituto Interuniversitario de Reconocimiento Molecular y Desarrollo Tecnológico (IDM), Unidad Mixta Universidad Politécnica de Valencia-Universidad de Valencia, Spain

${ }^{b}$ Departamento de Química Orgánica. Universidad de Valencia, Doctor Moliner 50, Burjassot, 46100, Valencia, Spain.E-mail: ana.costero@uv.es

${ }^{\circ}$ Departamento de Química, Universidad Politécnica de Valencia, Camino de Vera $s / n$, 46022, Valencia, Spain. E-mail: rmaez@qim.upv.es

${ }^{d}$ CIBER de Bioingenieria, Biomateriales y Nanomedicina (CIBER-BBN), Spain

$\dagger$ Electronic supplementary information (ESI) available. See DOI: 10.1039/c6ra02222g
}

area of research. ${ }^{6}$ No standards have been agreed upon for nitrogen oxides in indoor air, moreover ASHRAE and the US EPA National Ambient Air Quality Standards list $0.053 \mathrm{ppm}$ as the average 24 hour limit for $\mathrm{NO}_{2}$ in outdoor air. ${ }^{7}$ However, $\mathrm{NO}_{2}$ levels in certain cities and at certain hours can reach even higher values (near $100 \mathrm{ppm}$ ).

Laser-based photoacoustic spectroscopy, ${ }^{8}$ surface acoustic wave (SAW), ${ }^{9}$ transition metal oxide devices, ${ }^{10}$ carbon quantum dot-functionalized aerogels, ${ }^{11}$ or ozone treated graphen ${ }^{12}$ are some reported analytical techniques used to detect/monitor $\mathrm{NO}_{2}$ levels. However, some of these methods show certain limitations such as lack of specificity, limited selectivity, operational complexity, non-portability, difficulties in real-time monitoring and false positive readings. As an alternative to these instrumental procedures, the development of molecular chemosensors, constructed under the chemodosimeter paradigm, has been gaining interest in recent years. However, the number of publications related with optical probes for $\mathrm{NO}_{2}$ detection is still relatively scarce. ${ }^{13}$

Bearing in mind our interest in the development of chemical sensors for gas detection, ${ }^{14}$ we report herein the synthesis and sensing behavior towards $\mathrm{NO}_{2}$ of four new chemodosimeters based on the biphenyl chromophore. Among the different organic reactions involving $\mathrm{NO}_{2}$ we decided to explore the utility of the generation of aromatic aldehydes from trimethylsilyl benzyl ethers ${ }^{15}$ and oximes ${ }^{16}$ in order to prepare suitable chemodosimeters for the detection of this poisonous and pollutant gas. These are reactions with quantitative yields, working at room temperature and at ambient pressure. The synthesized biphenyl probes (vide infra) possess electron donor groups (such as methoxide electronically connected with trimethylsilyl) or oxime (weak electron acceptor) moieties. The 


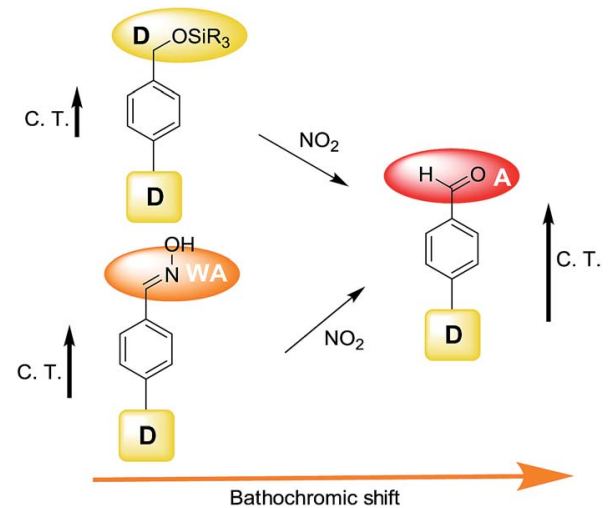

Scheme 1 Sensing protocol used for $\mathrm{NO}_{2}$ detection.

underlying idea is that, upon $\mathrm{NO}_{2}$ reaction, the formed aldehyde (an electron acceptor moiety) would change the electronic properties of the chemodosimeter with subsequent shifts of the absorption bands (see Scheme 1).

\section{Results and discussion}

Probes P1-P4 were prepared following the synthetic pathway depicted in Scheme 2. $\operatorname{Pd}(0)$ catalyzed cross-coupling reaction of the appropriate boronic acids ( $\mathbf{1}$ and 2$)$ with 4-bromohydroxymethylbenzene (3) or 4-bromobenzaldehyde (4) yielded the corresponding biphenyl derivatives bearing hydroxyl (5 and 6) or aldehyde ( 7 and 8 ) moieties. ${ }^{17}$ Transformation of the hydroxyl group into the corresponding trimethylsilyl ether (probes P1 and P2) was carried out using hexametildisilazane (HMDS) in dry $\mathrm{CH}_{2} \mathrm{Cl}_{2},{ }^{18}$ whereas the probes containing oximes (P3 and P4) were obtained with hydroxylamine hydrochloride in $\mathrm{H}_{2} \mathrm{O} / \mathrm{MeOH}$ mixed with sodium carbonate. ${ }^{19}$ All compounds were characterized by ${ }^{1} \mathrm{H}$ NMR, ${ }^{13} \mathrm{C}$ NMR and MS (see ESI $\dagger$ ). Acetonitrile solutions of the four probes $\left(1.0 \times 10^{-4} \mathrm{M}\right)$ showed intense absorption bands in the $260-300 \mathrm{~nm}$ region with $\varepsilon$ values ranging from 6000 to $15000 \mathrm{M}^{-1} \mathrm{~cm}^{-1}$.

In a first step, the absorption changes of probes P1-P4 $(1.0 \times$ $10^{-4} \mathrm{M}$ in acetonitrile) after bubbling $1 \mathrm{ppm}$ of $\mathrm{NO}_{2}$ during 5 min (obtained from a commercial cylinder), was tested.

Acetonitrile solutions of P1 showed an absorption band centered at $277 \mathrm{~nm}$ that was redshifted to $285 \mathrm{~nm}$ upon

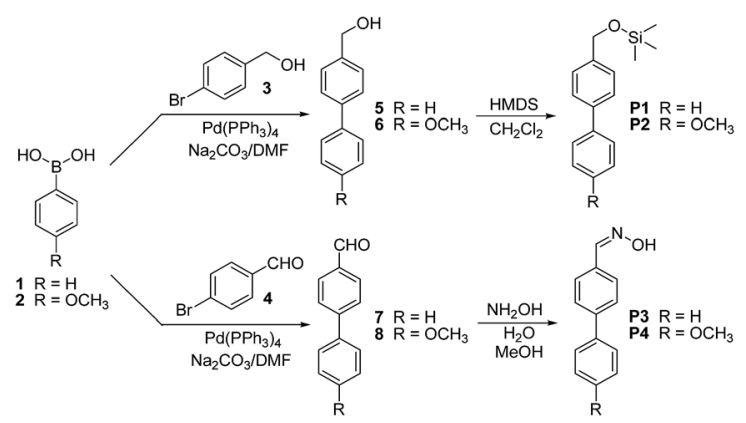

Scheme 2 Synthetic pathways used for the preparation of probes P1-P4. bubbling air containing $1 \mathrm{ppm}$ of $\mathrm{NO}_{2}$ (see Fig. 1). Interestingly, the same absorption band centered at $285 \mathrm{~nm}$ was observed upon bubbling $\mathrm{NO}_{2}$ into acetonitrile solutions of probe $\mathbf{P} 3$ (see also Fig. 1). The new absorption band, formed upon $\mathrm{NO}_{2}$ bubbling, was ascribed to the formation of aldehyde 7 as a consequence of the oxidative deprotection of the trimethylsilyl ether moiety in P1 and of the rupture of the oxime group in P3. In fact both, the UV and ${ }^{1} \mathrm{H}$ NMR spectra of aldehyde 7 , were fully coincident with that obtained after treatment of probes P1 and $\mathbf{P 3}$ with $\mathrm{NO}_{2}$. Optically, the transformation of an electron donor (trimethylsilyl ether in P1) or a weak electron acceptor (oxime in P3) group into an aldehyde (with a marked ability to attract electronic density) yielding 7 , resulted in a bathochromic shift of the absorption band of $\mathbf{P 1}$ and $\mathbf{P 3}$. A similar redshifts of the absorption bands of acetonitrile solutions of $\mathbf{P 2}$ and $\mathbf{P 4}$ was observed upon bubbling $\mathrm{NO}_{2}$ (1 ppm in air) (see Fig. 1). These changes were ascribed to the reaction of $\mathrm{NO}_{2}$ with the probes that yielded in both cases aldehyde 8. Also in this case it was found that the UV and ${ }^{1} \mathrm{H}$ NMR spectra of aldehyde 8 , were fully coincident with that obtained after treatment of probes $\mathbf{P} 2$ and $\mathbf{P 4}$ with $\mathrm{NO}_{2}$. The best sensing performance, in terms of a larger shift of the absorption band, was obtained for probe $\mathbf{P 2}$, for which a redshift of $45 \mathrm{~nm}$ (from 264 to $309 \mathrm{~nm}$ ) was observed upon bubbling $1 \mathrm{ppm}$ of $\mathrm{NO}_{2}$. For this reason, further detailed studies with $\mathbf{P} 2$ were carried out in order to assess the sensitivity and selectivity of this probe toward $\mathrm{NO}_{2}$.

The limit of detection (LOD) using $\mathbf{P 2}$ for $\mathrm{NO}_{2}$ was determined by UV measurements by bubbling increasing amounts of $\mathrm{NO}_{2}$ into an acetonitrile solution of the probe. As shown in Fig. 2, the absorbance at $309 \mathrm{~nm}$ was gradually enhanced when the concentration of $\mathrm{NO}_{2}$ increases. From the titration profile a LOD as low as $0.02 \mathrm{ppm}$ was calculated.

In a second step, the selectivity of $\mathbf{P} \mathbf{2}$ was assessed. This is an important issue in the design of probes for pollutant gases in order to overcome potential interferents or false-positive readings produced by other species. Taking this into account, the potential reactivity of probe $\mathbf{P 2}$ with other hazardous gases (i.e. $\mathrm{NO}, \mathrm{CO}_{2}, \mathrm{H}_{2} \mathrm{~S}, \mathrm{SO}_{2}$ ) or organic vapors (i.e. acetone, hexane, chloroform, acetonitrile, toluene) was tested by bubbling the selected species into acetonitrile solution of P2 $\left(1.0 \times 10^{-4} \mathrm{M}\right)$. None of the gases tested, at concentrations up to $100 \mathrm{ppm}$, induced changes in the UV
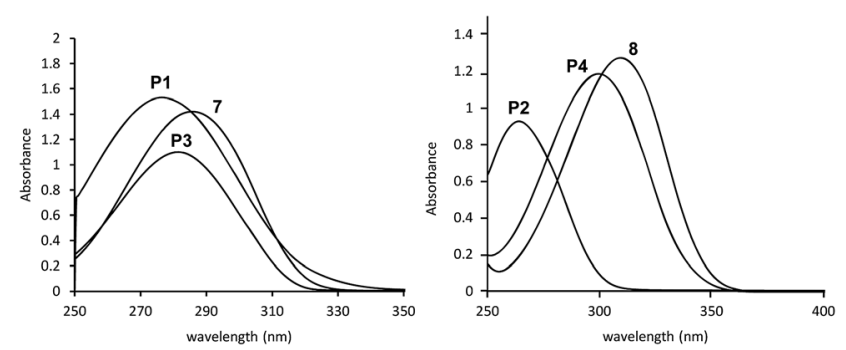

Fig. 1 (Left) UV spectra of probes $\mathrm{P} 1$ and $\mathrm{P} 3\left(1.0 \times 10^{-4} \mathrm{M}\right.$ in acetonitrile) alone and after bubbling $1 \mathrm{ppm}$ of $\mathrm{NO}_{2}$ during $5 \mathrm{~min}$. (Right) UV spectra of probes P2 and P4 $\left(1.0 \times 10^{-4} \mathrm{M}\right.$ in acetonitrile) alone and after bubbling $1 \mathrm{ppm}$ of $\mathrm{NO}_{2}$ during $5 \mathrm{~min}$. The reactions gave aldehydes 7 and 8 , respectively. 


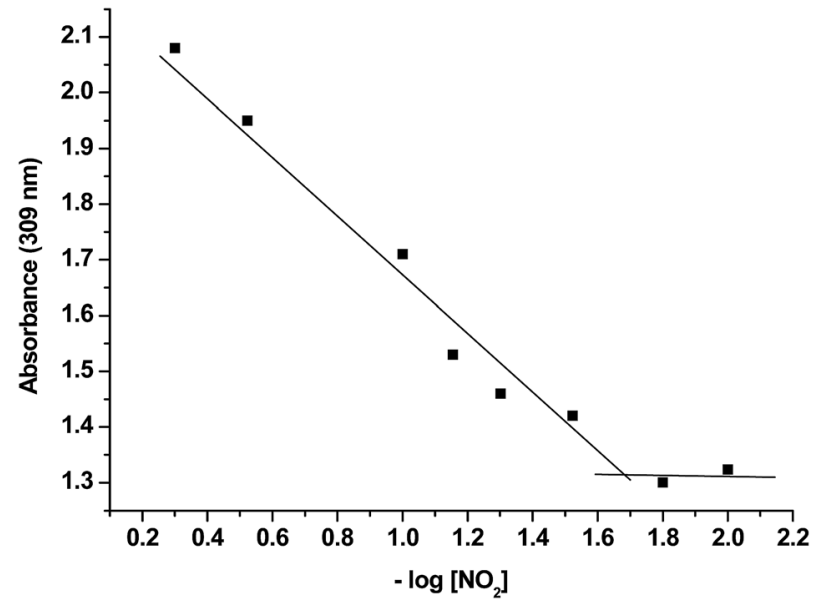

Fig. 2 Absorbance at $309 \mathrm{~nm}$ measured after bubbling increasing quantities of $\mathrm{NO}_{2}$ into acetonitrile solutions of probe P2 $\left(1.0 \times 10^{-4} \mathrm{M}\right)$.

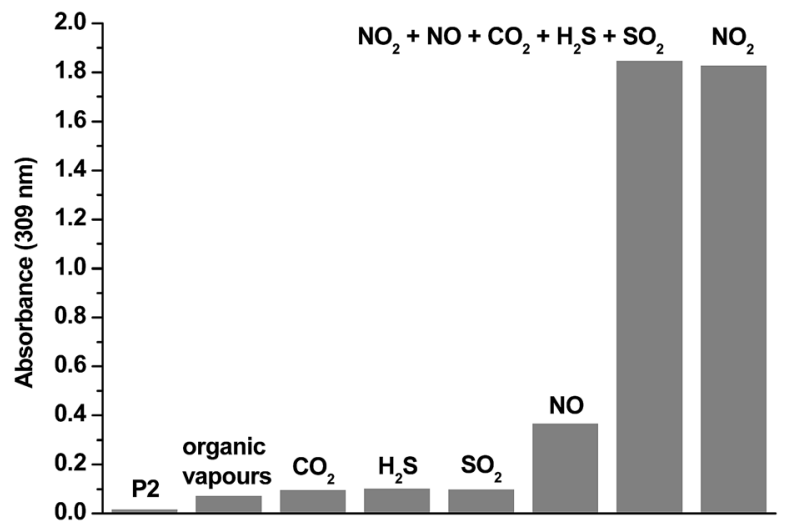

Fig. 3 Absorbance at $309 \mathrm{~nm}$ of probe P2 alone and in the presence of selected potential interferents (all compounds at a concentration of $100 \mathrm{ppm})$.

spectra of probe $\mathbf{P} 2$ indicating a high selective reaction of $\mathbf{P} 2$ with $\mathrm{NO}_{2}$ (see Fig. 3).

Competitive studies were also carried out. Thus, Fig. 3 shows that the absorption of the band at $309 \mathrm{~nm}$ of probe $\mathbf{P 2}$ in the presence of a complex gas mixture $\left(\mathrm{NO}_{2}+\mathrm{NO}+\mathrm{CO}_{2}+\mathrm{H}_{2} \mathrm{~S}+\mathrm{SO}_{2}\right)$ was the same than that observed when $\mathrm{NO}_{2}$ was used alone. This result demonstrated a high selective response of probe $\mathbf{P 2}$ toward $\mathrm{NO}_{2}$ and suggested its possible use for the detection/ monitoring of this poisonous gas.

\section{Conclusions}

Four new biphenyl-based probes P1-P4 have been synthesized and used for the selective recognition of $\mathrm{NO}_{2}$. For all four probes a bathochromic shift of the absorption bands was observed in the presence of the $\mathrm{NO}_{2}$ and ascribed to the generation of an aromatic aldehyde upon reaction of $\mathrm{NO}_{2}$ with trimethylsilyl benzyl ether or oxime groups contained in P1-P2 and P3-P4, respectively. Among the prepared chemosensors, $\mathbf{P} 2$ showed the higher shift of the absorption band and for this probe a LOD as low as $0.02 \mathrm{ppm}$ was determined for $\mathrm{NO}_{2}$ detection. Moreover, the response of $\mathbf{P 2}$ was highly selective and no reaction was found in the presence of $\mathrm{NO}, \mathrm{CO}_{2}, \mathrm{H}_{2} \mathrm{~S}, \mathrm{SO}_{2}$ or organic vapors of acetone, hexane, chloroform, acetonitrile or toluene. We believe that these, or similar probes based in the same chemical reaction, can display a large potential as optical probes for the selective detection of $\mathrm{NO}_{2}$.

\section{Experimental section}

\section{General remarks}

Dichloromethane and acetonitrile were distilled from $\mathrm{P}_{2} \mathrm{O}_{5}$ under Ar prior to use. Silica gel 60 F254 (Merck) plates were used for TLC. Colum chromatography was performed on silica gel. ${ }^{1} \mathrm{H}$ and ${ }^{13} \mathrm{C}$ NMR spectra were determined on a Bruker AV 300 spectrometer. Chemical shifts are reported in parts per million (ppm), calibrated to the solvent peak set. High-resolution mass spectra were recorded in the positive ion mode with a VG-AutoSpec mass spectrometer. Absorption and fluorescence spectra were recorded using a Shimadzu UV-2600 spectrophotometer.

\section{Synthesis of biphenyl alcohols 5 and 6}

In a typical run, the corresponding boronic acid ( $\mathbf{1}$ for the synthesis of $5 ; 2$ for the preparation of $\mathbf{6})(2 \mathrm{mmol})$ was added, to a solution of $3(1 \mathrm{mmol})$ in DMF $(20 \mathrm{~mL})$ in the presence of sodium carbonate $(6 \mathrm{mmol})$. Afterward, the flask was evacuated and refilled with argon. Then, tetrakis(triphenylphosphine) palladium(0) was added and the crude obtained heated at 100 ${ }^{\circ} \mathrm{C}$ for 30 minutes with vigorous stirring. The resultant mixture was diluted with $\mathrm{H}_{2} \mathrm{O}(10 \mathrm{~mL})$ and $\mathrm{Et}_{2} \mathrm{O}(10 \mathrm{~mL})$, followed by extraction twice with $\mathrm{Et}_{2} \mathrm{O}$. The ethereal extract was collected and the solvent evaporated under vacuum. The final product was isolated by column chromatography on silica, with hexane/ ethyl acetate $(8: 2)$ as eluent, yielding a colourless solid (65\%).

\section{5}

(65\%), colourless solid. ${ }^{1} \mathrm{H}$ NMR (300 MHz, DMSO) $\delta$ (ppm): 7.68-7.60 (m, 4H), 7.50-7.32 (m, 5H), $5.21(\mathrm{t}, J=5.7 \mathrm{~Hz}, 1 \mathrm{H})$, $4.54(\mathrm{~d}, J=5.7 \mathrm{~Hz}, 2 \mathrm{H}) .{ }^{13} \mathrm{C}$ NMR $(75 \mathrm{MHz}, \mathrm{DMSO}) \delta(\mathrm{ppm}):$ 142.2, 140.5, 138.9, 129.3, 127.6, 127.4, 126.9, 126.7, 62.9.

\section{6}

(67\%), colourless solid. ${ }^{1} \mathrm{H}$ NMR (300 MHz, DMSO) $\delta(\mathrm{ppm})$ : $7.50-7.43(\mathrm{~m}, 4 \mathrm{H}), 7.37$ (d, $J=8.4 \mathrm{~Hz}, 2 \mathrm{H}), 6.91$ (d, $J=8.7 \mathrm{~Hz}$, $2 \mathrm{H}), 5.20(\mathrm{t}, J=5.7 \mathrm{~Hz}, 1 \mathrm{H}), 4.53(\mathrm{~d}, J=5.7 \mathrm{~Hz}, 2 \mathrm{H}), 3.79(\mathrm{~s}, 3 \mathrm{H})$. ${ }^{13} \mathrm{C}$ NMR (75 MHz, DMSO) $\delta$ (ppm): 159.1, 132.9, 132.8, 132.7, 127.9, 127.4, 126.2, 114.7, 63.0, 55.6.

\section{Synthesis of probes P1 and P2}

HDMS (40 mmol) was added to the corresponding alcohol $(20 \mathrm{mmol})$ in dry dichloromethane $(20 \mathrm{~mL})$. The mixture was stirred at room temperature for $22 \mathrm{~h}$ (full conversion) under argon atmosphere. The solvent was evaporated and the crude was purified by column chromatography on silica using hexane/ 
ethyl acetate (8 : 2) as eluent, to give the probes P1 (90\%) or P2 $(93 \%)$ as white solids.

P1

(90\%), white solid, mp $158-160{ }^{\circ} \mathrm{C} .{ }^{1} \mathrm{H}$ NMR (300 MHz, DMSO) $\delta(\mathrm{ppm}): 7.50(\mathrm{~m}, 4 \mathrm{H}), 7.27(\mathrm{~m}, 5 \mathrm{H}), 4.56(\mathrm{~s}, 2 \mathrm{H}), 0.00(\mathrm{~s}, 9 \mathrm{H}) .{ }^{13} \mathrm{C}$ NMR (75 MHz, DMSO) $\delta$ (ppm): 140.5, 140.3, 139.2, 129.2, 127.6, $127.3,126.9,63.8,-0.1$. UV-Vis (acetonitrile) $\lambda_{\max }=277 \mathrm{~nm}(\varepsilon=$ $\left.15300 \mathrm{M}^{-1} \mathrm{~cm}^{-1}\right)$.

\section{P2}

(93\%), white solid, mp 170-173 ${ }^{\circ} \mathrm{C} .{ }^{1} \mathrm{H}$ NMR (300 MHz, DMSO) $\delta$ (ppm): $7.45(\mathrm{~m}, 4 \mathrm{H}), 7.22(\mathrm{~d}, J=8.4 \mathrm{~Hz}, 2 \mathrm{H}), 6.88(\mathrm{~d}, J=8.5 \mathrm{~Hz}$, $2 \mathrm{H}), 4.55$ (s, 2H), $3.66(\mathrm{~s}, 3 \mathrm{H}), 0.00(\mathrm{~s}, 9 \mathrm{H}) .{ }^{13} \mathrm{C}$ NMR $(75 \mathrm{MHz}$, DMSO) $\delta$ (ppm): 139.6, 138.8, 132.6, 129.2, 127.9, 127.3, 126.2, 114.6, 63.8, 0.1. UV-Vis (acetonitrile) $\lambda_{\max }=264 \mathrm{~nm}(\varepsilon=8000$ $\left.\mathrm{M}^{-1} \mathrm{~cm}^{-1}\right)$.

\section{Synthesis of 7 and 8}

$4(1.5 \mathrm{mmol})$ and 1 or 2 for 7 and 8 respectively ( $3 \mathrm{mmol})$ were dissolved in DMF $(20 \mathrm{~mL})$. Afterward, sodium carbonate (9 mmol) was added to this solution. The crude reaction was stirred under inert atmosphere for $30 \mathrm{~min}$. Then, a catalytic amount of tetrakis(triphenylphosphine)palladium(0) was added and the reaction was stirred at $100{ }^{\circ} \mathrm{C}$ for 10 minutes. After this time water $(10 \mathrm{~mL})$ was added and the mixture was extracted with ethyl acetate $(2 \times 20 \mathrm{~mL})$. The organic phase was washed with brine $(2 \times 20 \mathrm{~mL})$, dried with $\mathrm{MgSO}_{4}$ and evaporated to give the product.

7 was purified by silica column chromatography with hexane/ethyl acetate $(9: 1)$ to give a white crystalline solid (82\%). ${ }^{1} \mathrm{H}$ NMR (300 MHz, DMSO- $\left.d_{6}\right) \delta 10.06(\mathrm{~s}, 1 \mathrm{H}), 8.01(\mathrm{~m}$, $2 \mathrm{H}), 7.92(\mathrm{~d}, J=8.3 \mathrm{~Hz}, 2 \mathrm{H}), 7.78(\mathrm{~m}, 2 \mathrm{H}), 7.50(\mathrm{~m}, 3 \mathrm{H}) .{ }^{13} \mathrm{C} \mathrm{NMR}$ (75 MHz, DMSO- $d_{6}$ ) $\delta 193.20,146.34,139.27,135.56,130.62$, 129.60, 129.06, 127.84, 127.60. HRMS (EI): $m / z$ calc. for $\mathrm{C}_{13} \mathrm{H}_{10} \mathrm{O}$ 182.07 $[\mathrm{M}+1]^{+}$found: $183.0797 \mathrm{UV}$-Vis (acetonitrile) $\lambda_{\max }=289$ $\mathrm{nm}\left(\varepsilon=9500 \mathrm{M}^{-1} \mathrm{~cm}^{-1}\right)$.

8 was purified by silica column chromatography with hexane/ethyl acetate $(8: 2)$ to give a white crystalline solid (75\%). ${ }^{1} \mathrm{H}$ NMR (300 MHz, DMSO- $\left.d_{6}\right) \delta 10.03(\mathrm{~s}, 1 \mathrm{H}), 8.01-7.93$ $(\mathrm{m}, 2 \mathrm{H}), 7.91-7.85(\mathrm{~m}, 2 \mathrm{H}), 7.74(\mathrm{~d}, J=9.0 \mathrm{~Hz}, 2 \mathrm{H}), 7.08(\mathrm{~d}, J=$ $8.9 \mathrm{~Hz}, 2 \mathrm{H}), 3.82$ (s, 3H). ${ }^{13} \mathrm{C}$ NMR (75 MHz, DMSO) $\delta$ (ppm): 192.9, 160.2, 145.9, 134.8, 131.3, 130.5, 128.7, 127.0, 114.9, 55.6. HRMS (EI): $m / z$ calc. for $\mathrm{C}_{14} \mathrm{H}_{12} \mathrm{O}_{2} 212.08[\mathrm{M}+1]^{+}$found: 213.0901. UV-Vis (acetonitrile) $\lambda_{\max }=309 \mathrm{~nm}\left(\varepsilon=12700 \mathrm{M}^{-1}\right.$ $\left.\mathrm{cm}^{-1}\right)$.

\section{Synthesis of probes P3 and P4}

The corresponding aldehyde ( 7 and $\mathbf{8}$ for $\mathbf{P 3}$ and $\mathbf{P 4}$ respectively, $2 \mathrm{mmol})$ and hydroxylamine hydrochloride $(2.2 \mathrm{mmol})$ were dissolved in methanol-water $(1: 1,40 \mathrm{~mL})$. A previously prepared solution of sodium carbonate $(2 \mathrm{mmol})$ in water was slowly added and the reaction was stirred for $3 \mathrm{~h}$ at room temperature. Then, methanol was evaporated and the aqueous phase was extracted with ether $(4 \times 40 \mathrm{~mL})$. The organic phase was washed with brine $(1 \times 30 \mathrm{~mL})$ and dried with $\mathrm{MgSO}_{4}$. After evaporation of the solvent probes P3 (99\%) and P4 (77\%) were isolated as white solids.

P3

(99\%), white crystalline solid, mp 142-145 ${ }^{\circ} \mathrm{C} .{ }^{1} \mathrm{H}$ NMR (300 MHz, DMSO- $\left.d_{6}\right) \delta 11.28(\mathrm{~s}, 1 \mathrm{H}), 8.19(\mathrm{~s}, 1 \mathrm{H}), 7.70(\mathrm{~m}, 6 \mathrm{H}), 7.48$ $(\mathrm{m}, 2 \mathrm{H}) 7.40(\mathrm{~m}, 1 \mathrm{H}) .{ }^{13} \mathrm{C} \mathrm{NMR}$ (75 MHz, DMSO) $\delta$ (ppm): 148.1, 141.2 139.8, 132.6, 129.3, 128.1, 127.3, 127.3, 126.9. HRMS (EI): $m / z$ calc. for $\mathrm{C}_{13} \mathrm{H}_{11} \mathrm{NO} 197.08[\mathrm{M}+1]^{+}$found: 198.0913. UV-Vis (acetonitrile) $\lambda_{\max }=282 \mathrm{~nm}\left(\varepsilon=5800 \mathrm{M}^{-1} \mathrm{~cm}^{-1}\right)$.

\section{P4}

(77\%), white crystalline solid, mp $165-167{ }^{\circ} \mathrm{C} .{ }^{1} \mathrm{H}$ NMR (300 MHz, chloroform- $d$ ) $\delta 8.09(\mathrm{~s}, 1 \mathrm{H}), 7.50(\mathrm{~m}, 5 \mathrm{H}), 6.92(\mathrm{~d}, J=8.9$ $\mathrm{Hz}, 2 \mathrm{H}), 5.23$ (s, 1H), 3.79 (s, 3H). ${ }^{13} \mathrm{C}$ NMR (75 MHz, DMSO) $\delta$ (ppm): 159.5, 148.2, 140.9, 134.8, 130.5, 128.7, 128.1, 127.0, 114.9, 55.6. HRMS (EI): $m / z$ calc. for $\mathrm{C}_{14} \mathrm{H}_{13} \mathrm{NO}_{2} 227.09[\mathrm{M}+1]^{+}$ found: 228.1019 . UV-Vis (acetonitrile) $\lambda_{\max }=300 \mathrm{~nm}(\varepsilon=11800$ $\left.\mathrm{M}^{-1} \mathrm{~cm}^{-1}\right)$.

\section{Limits of detection measurements}

Increasing quantities of $\mathrm{NO}_{2}$ gas from commercially available $\mathrm{NO}_{2}$ cylinder were bubbled for 5 min through a solution of $\mathbf{P 2}$ in acetonitrile. The UV spectra were recorded in $1 \mathrm{~cm}$ path length cells at $25{ }^{\circ} \mathrm{C}$. Representation of the wavelength (nm) vs. concentration of $\mathrm{NO}_{2}$ allowed the limit of detection to be calculated by using the eqn (1)

$$
\mathrm{LOD}=3 s_{\mathrm{b}} / m
$$

in which $s_{\mathrm{b}}$ is the standard deviation of blank measurements and $m$ is the slope of the linear regression plot.

\section{Acknowledgements}

We thank the Spanish Government and FEDER founds (MAT201238429-C04) and Generalitat Valenciana (PROMETEOII/2014/047) for support. SCSIE (Universidad de Valencia) is gratefully acknowledged for all the equipment employed.

\section{References}

1 K. Skalska, J. S. Miller and S. Ledakowicz, Sci. Total Environ., 2010, 408, 3976-3989.

2 S. C. Barman, N. Kumar, R. Singh, G. C. Kisku, A. H. Khan, M. M. Kidwai, R. C. Murthy, M. P. S. Negi, P. Pandey, A. K. Verma, G. Jain and S. K. Bhargava, J. Environ. Biol., 2010, 31, 913-920.

3 Analytical Techniques for Atmospheric Measurement, ed. D. Heard, John Wiley \& Sons, 2008, p. 331.

4 (a) J. L. Devalia, A. M. Campbell, R. J. Sapsford, C. Rusznak, D. Quint, P. Godard, J. Bousquet and R. J. Davies, Am. J. Respir. Cell Mol. Biol., 1993, 9, 271-278; (b) S. M. Horvath, Bull. N. Y. Acad. Med., 1980, 56, 835-846. 
5 (a) W. S. Tunnicliffe, P. S. Burge and J. G. Ayres, Lancet, 1994, 344, 1733-1736; (b) M. Shima and M. Adachi, Int. J. Mol. Epidemiol. Genet., 2000, 29, 862-870.

6 (a) H. Dehghani, M. Bezhgi, R. Malekzadeh, E. Imani, S. Pasban-Noghabi, G. Javadi, R. Faraji, M. Negahdary and R. Aghebati-Maleki, Int. J. Electrochem. Sci., 2014, 9, 14541467; (b) M. Zhao, T. Zhang, J. Wang and Z. Yuan, J. Network, 2013, 8, 405-412; (c) J. Z. Ou, W. Ge, B. Carey, T. Daeneke, A. Rotbart, W. Shan, Y. Wang, Z. Fu, A. F. Chrimes, W. Wlodarski, S. P. Russo, Y. X. Li and K. Kalantar-Zadeh, ACS Nano, 2015, 9, 10313-10323.

7 U.S. Environmental Protection Agency (EPA), Non-cancer Health Effects (RELS), Office of Environmental Health Hazard Assessment (OEHHA), California, DC, USA, 1999.

8 A. Mukherjee, M. Prasanna, M. Lane, R. Go, I. Dunayevskiy, A. Tsekoun, C. Kumar and N. Patel, Appl. Opt., 2008, 47, 4884-4887.

9 A. Venema, E. Nieuwkoop, M. J. Vellekoop, M. S. Nieuwenhuizen and A. W. Barendsz, Sens. Actuators, 1986, 10, 47-64.

10 (a) W. K. Nomani, D. Kersey, J. James, D. Diwan, T. Vogt, R. A. Webb and G. Koley, Sens. Actuators, B, 2011, 160, 251-259; (b) D. Zhang, Z. Liu, C. Li, T. Tang, X. Liu, S. Han, B. Lei and C. Zhou, Nano Lett., 2004, 4, 1919-1924; (c) S.-W. Choi, A. Katoch, G. J. Sun, P. Wu and S. S. Kim, J. Mater. Chem. C, 2013, 1, 2834-2841; (d) X. Liang, S. Yang, J. Li, H. Zhang, Q. Diao, W. Zhao and G. Lu, Sens. Actuators, B, 2011, 158, 1-8.
11 R. Wang, G. Li, Y. Dong, Y. Chi and G. Chen, Anal. Chem., 2013, 85, 8065-8069.

12 M. G. Chung, D. H. Kim, H. M. Lee, T. Kim, J. H. Choi, D. K. Seo, J.-B. Yoo, S.-H. Hong, T. J. Kang and Y. H. Kim, Sens. Actuators, B, 2012, 166-167, 172-176.

13 (a) L. A. Juárez, A. M. Costero, M. Parra, S. Gil, F. Sancenón and R. Martínez-Máñez, Chem. Commun., 2015, 51, 17251727; (b) J. Mokhari, M. R. Naimi-Jamal and H. Hamzehal, 11th International Electronic Conference on Synthetic Organic Chemistry (ECSOC-11), November 2007, pp. 1-30.

14 (a) A. Martí, A. M. Costero, P. Gaviña and M. Parra, Chem. Commun., 2015, 51, 3077-3079; (b) L. A. Juárez, A. BarbaBon, A. M. Costero, R. Martínez-Máñez, F. Sancenón, M. Parra, P. Gaviña, M. C. Terencio and M. J. Alcaraz, Chem.-Eur. J., 2015, 21, 15450.

15 S. Ohira, E. Wanigasekara, R. D. Rudkevich and P. K. Dasgupta, Talanta, 2009, 79, 14-20.

16 M. Javaheri, M. R. Naimi-Jamal, M. G. Dekamin and G. Kaupp, Phosphorus, Sulfur Silicon Relat. Elem., 2012, 187, 142-148.

17 C. M. Nunes and A. L. Monteiro, J. Braz. Chem. Soc., 2007, 18, 1443-1447.

18 J. Marjan, Tetrahedron, 2012, 68, 3861-3867.

19 S. Castellano, D. Kuck, M. Viviano, J. Yoo, F. López-Vallejo, P. Conti, L. Tamborini, A. Pinto, J. L. Medina-Franco and Y. G. Sbardella, J. Med. Chem., 2011, 54, 7663-7677. 